\title{
A Designed Eco-Art and Place-Based Curriculum Encouraging Students' Empathy for the Environment
}

\author{
Asvina Sunassee and Chandradeo Bokhoree *
}

check for updates

Citation: Sunassee, A.; Bokhoree, C. A Designed Eco-Art and Place-Based Curriculum Encouraging Students' Empathy for the Environment. Ecologies 2021, 2, 248-267. https:// doi.org/10.3390/ecologies2030014

Received: 26 May 2021

Accepted: 25 June 2021

Published: 28 June 2021

Publisher's Note: MDPI stays neutral with regard to jurisdictional claims in published maps and institutional affiliations.

Copyright: (c) 2021 by the authors. Licensee MDPI, Basel, Switzerland. This article is an open access article distributed under the terms and conditions of the Creative Commons Attribution (CC BY) license (https:// creativecommons.org/licenses/by/ $4.0 /)$.
School of Sustainable Development and Tourism, University of Technology, La Tour Koenig, Mauritius; sunasseea@live.com

* Correspondence: sbokhoree@umail.utm.ac.mu

\begin{abstract}
Environmental art education is gaining importance in schools as arts education begins to acquire a more significant role in environmental education. This emerging field of study is an interdisciplinary endeavor that is centered on the different fields of environmental education and visual art education and provides a means of making students aware of environmental issues through environmental art education. It has been suggested that students get into a relationship with nature prior to the request to conserve the environment in order to be nature connected. This abstract focuses on teaching and learning through the arts, a pedagogical way in which students discuss the challenging aspects of environmental issues. The aim of this study is to make students act like protectors of their environment through an eco-art place-based curriculum. This paper's pedagogies will provide educators with a framework for developing environmental art education lessons and curricula. This experimental study has been planned to gather data from interviews and observation of students and by making the students participate in nature-related activities. The findings show that students prefer to let go of their fascination with formulating better ecological perspectives. On the positive side, a few students went through some frustration during the program and the activities. Students have given positive feedback on the program in positive terms, such as "fun", "interesting", and "cool", to express their experience gained through the class activities.
\end{abstract}

Keywords: eco-art education; empathy; place-based education; environment; art education; curriculum; pro-environmental behavior

\section{Introduction}

Everyone is affected by environmental issues. There is news describing different impacts on the environment, including water pollution, rising global warming, an increase in trash in the sea, and an increase in sea levels that will be dangerous for some islands. Though these warnings or adverse signals are received in the global context, we can still experience some of the problems in our own society. When an individual disregards his or her responsibility to nature, the cumulative effect of such individuals may affect the entire world in a broad context, and everyone will suffer as a result. The researchers stated that this problem came into existence in the late 20th century [1,2]. They also mentioned that insufficient information and lack of direct contact with the environment have become major issues. Due to this, humans are causing deforestation, excess consumption, and pollution that is harming the environment. The reasons may be the absence of environmental education and empathy for the environment [3]. Empathy should be built into school education, and researchers have stated that the absence of eco-art education in schools has created this destruction by causing adults to have no empathy towards the environment.

According to the present context, it seems that people do not want to learn about the environment or the earth as they do not have any experience with it. However, Louise Chawla, who is an environmental psychologist, advised that learning through her own experience was better than learning from others when it came to environmental education [4]. She also mentioned how place attachments and personal relationships, both of which are 
forms of outdoor learning, can help to protect places and people. This opportunity offers an amazing platform for children to learn empathy for the environment and for all living things. Additionally, this helps to raise students' environmental awareness.

Empathy, which simply means "to feel within", originated from a German concept called "Einfühlung", and the meaning of "empathy" is the reaction of an individual to an object or living being [5,6]. Moreover, empathy is further developed to describe an aesthetic experience. This strong bond makes art education an essential element in developing empathy towards environmental concerns. We, as art educators, should increase students' empathy by encouraging them to participate in their artwork. Forbes, for example, explained the connection with the plant after a long period of observation and revealed some positive aspects. She explained that this observation had increased her empathy towards nature [7]. Additionally, artists create some concerns regarding nature, society, the earth, and the environment that reflect our relationship with the world. Their work is useful to enhance the ecological relationship in a more meaningful manner and increase the awareness towards nature. According to researchers, children should be exposed to nature on their own. Moreover, Hull stated that students should be given independence to experience it by responding [8]. It is identified that involvement and experience are major things in building up a relationship, and the same concept is applied to the environment too.

However, environmental education should be incorporated into school systems to enhance this relationship. It is said that place-based education is ideal for modifying education [9]. The reason is that place-based education facilitates students to learn through experience, and student-centered approaches make it easy to communicate with students. The education system can create connections between the environment and students' reallife experiences that are full of emotions. The feelings and attitudes in those experiences help the students to create a relationship and prepare the students to protect the earth and the community. In addition, a place-based system is an educational tactic that leads to many advantages, such as exploring nature and aesthetic experiences [10]. It aids as a knowledge strategy for youngsters to study the major elements of eco-art concepts, which comprise notions such as interdependence, preservation, and sustainability. Educational researchers promote the integration of place-based education and eco-art education to enable empathetic understanding and address ecological issues [11].

Leaders should formulate educational proposals to promote student engagement in order to build a community of sustainability. This requires schools to enable students to maintain sustainable lifestyles. In Mauritius, the government is promoting the green island of Mauritius and has already developed a variety of strategies to increase environmental awareness among Mauritians, particularly from an early age $[12,13]$. Stanisstreet argued that environmental campaigns in schools and educational institutions are important to the effective integration of the idea of environmental education [14]. Research has clearly shown that teachers give students many opportunities to increase their skills and knowledge by enthusiastically entering the community by teaching them about environmental concerns and issues. This will make it possible for students to become confident environmental protectors. This paper aims to demonstrate a successfully designed curriculum that has been implemented to develop students' empathy in order for them to adopt a more environmentally sustainable approach. This paper will also motivate other teachers to use this designed curriculum in their teaching.

\section{Materials and Methods}

\subsection{Experimental Study}

This experimental study intends to collect data through in-depth observation of students by examining students' empathy for the environment as a result of a designed eco-art and place-based curriculum, including what students believe, think, feel, and say about their direct experiences with the natural environment. The sample consisted of 25 male students aged 14 years old. The students were used to understand the empathy level for the environment. For this study, pre-test and post-test drawing exercises were 
included in the designed curriculum to observe students' empathy for the environment. Instructions were given for them to draw an incident or time where they got closer to the environment. They appreciated natural phenomena and articulated their thought processes in words on the back of their sketch pads. The students described their drawing exercise in words on the back page of their sketch pad. These discussions have allowed us to have in-depth knowledge about evaluation before and after test scenarios. A "typical" case is important as there were no such studies conducted in this field. However, this case study is identified as "unique" [15]. Qualitative methods play a great role in this complicated, single case. The teacher-researcher role was the main approach in this study. Hence, the teacher played the role of a researcher. Rather than using other teachers' classrooms, the students in my classroom were chosen for this study because they were familiar with me as a teacher-researcher. My familiarity and friendship aided in providing additional insights into the research. Another factor was that my class was smaller than the other three classes and it was more representative of a typical art class.

\subsection{Characteristics of the Case}

The public school is located in the north of Mauritius. There are approximately 1200 students ranging in age from 12 to 20 years. The school compound consists of several landscaped courtyards, including a playground, and segments of trees and natural growth at the back of the school. Additionally, the school offers many clubs for the activity period, such as the art club program, DUKE program, lecture program, health and safety programs, and others where students are required to participate as they are part of the school requirements. The subject period is about $70 \mathrm{~min}$ per subject, and the students can select a subject from electives from a minimum of 15 years old. The art club program was founded by an art teacher in 2016. The art club is a classroom consisting of two storage cabinets and shelves, a whiteboard, critique walls to display students' works, and tables for students and the teacher. One wall of the room consists of windows. The achievement level of students varies. However, there is a higher percentage of significant achievers or academically talented people. This class is a typical class where there are no students with learning disabilities. However, the socio-economic level of the families of the students varies and has a high range. This class was used to do a place-based art study. The goal of this research was to find ways to get closer to the environment, to imagine ecological changes, and to engage in responsible activities as a responsible citizen. The curriculum had recommendations, which were nature studies, history and culture, and transformative education that were appropriate for place-based art pedagogy [16]. Apart from that, placebased education involved listening to senior student speakers from DUKE, taking a nature walk, or gathering information about environmental artists.

\subsection{Data Collected}

\subsubsection{Observational Data Collected}

According to one researcher, students' observations are based on "first-hand experience of naturally occurring events" (p. 49) [17]. The involvement of the researcher can vary from non-participating to full participation. The teacher-researcher played a significant role here by actively participating in class activities and gathering data from the behavior of students regarding empathy for the environment. The teacher observed the activities of the students to collect data. The majority of qualitative research questions were answered through observation and detailed explanation. These observations were conducted throughout the data collection period from the beginning. As a teacher-researcher, observations were recorded regularly to know how the activities in the curriculum and methods were applied, to analyze the empathetic behavior of students, and for documentation purposes. Empathy can be related to any other person, animal, or plant, not just the environment. Planting a tree, watering a plant, going for a nature walk, appreciating nature, sharing art materials among students, and participating by showing interest in senior students from DUKE who care about the environment are examples of the behaviors. 


\subsubsection{Student Sketch Pad}

The use of image-based research has increased in recent years and it has been accepted as a valid research methodology for the social science community [18]. This research method can use found, researcher generated, or participant-generated images. To expose hidden emotional perspectives and to provide data triangulation, this study used participant-generated images that were created in a student's sketch pad. The students' sketch pad was created for these study requirements. See Figure 1.

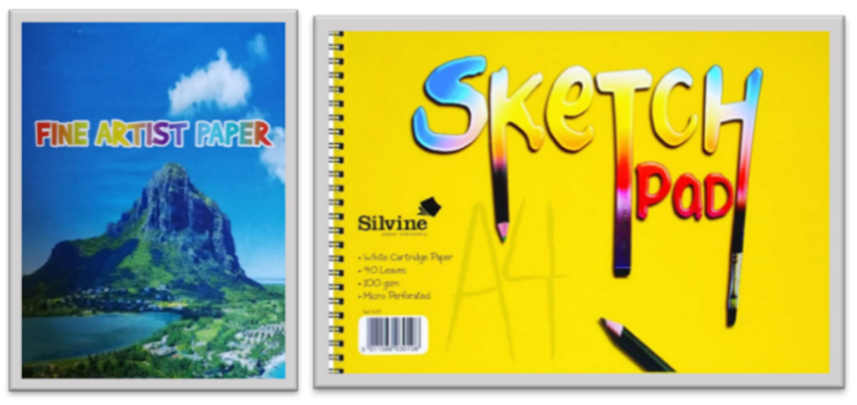

Figure 1. Students' sketch pad.

The sketch pad was also known as a sketchbook where students were encouraged to produce sketches or images of what they see and then write about them. This method included both writing and drawing. However, the control of the data was with the students, hence, the data ownership was retained by them. The teachers created some prompts and free sketches where the students responded once a week as part of this study. Apart from that, students used their sketch pads for their drawings to express themselves. This research methodology supports the designed curriculum as per the method of observation, and it expresses the relationship between student empathy and relationships. The empathy of students is exposed through art, pictures, drawing, text, or a combination of all, which reflects an appreciation of each other. The prompts shown by the teacher were open-ended, and students could freely think about their sketches and could use their own experience. It was identified that students revealed their real-life experiences through prompts when reviewing the documents. The teacher-researcher who showed the prompt did not explain it in detail and the students were asked to complete it. Then, students used their freethinking and worked to complete the sketch through group work where they did their work in school. Hence, the content of their sketches or images was critically molded by the responses of the other team members and by the awareness of the audience.

\section{Results}

\subsection{Relationships}

\subsubsection{Relationship with Their Friends}

This study is an observational research method used to gather data from the same sample of students repeatedly. This class was formed into friendship groups at the beginning of the art club. From the first day of class, once they entered the room, these groups were formed. Even though the seats were not assigned, the seating arrangement was not changed throughout the year. The best friend's group in the class consisted of four boys. This group consisted of both high- and middle-class families who were high achievers. They obviously knew each other well and had maintained a close friendship. Two were cousins and the rest were close friends from primary school. This group was usually seated together in class. Even when the seating places were changed, they would sit within the group. There were four friends in this group who interacted with one another. The students showed a connection with all the students. Another group of four boys had varying socioeconomic backgrounds and levels of achievement. The students were friendly with each other. Some students went around socializing before class began. The class was a heterogeneous group consisting of students with diversified backgrounds when it came 
to their education, interests, etc. However, the vast majority of them were high-achieving students. All of these students had different academic, social, and emotional backgrounds, but they were all the same age. Heterogeneous grouping favorably enabled students to learn from others about their differences. Furthermore, this method encouraged students to actively integrate with other students while sharing all of their abilities and interests with others. These students seemed to be very close and knew each other very well. Many of them had known each other since primary school. As the term progressed, the students were familiar with each other. Teachers had to wait longer for the students to stop talking so that they could start a lesson. The amount of socialization became more evident after students completed their eco-art projects. The group project motivated students to work together, and students felt very comfortable engaging with each other. When the assignments were finished, the students were not used to being quiet and listening. However, this conversation was not a big behavioral problem. The students treated their classmates with respect and offered artistic encouragement to each other. During criticism, students gave positive and constructive feedback to each other. In building their eco-artwork, the students shared the resources they took home with the other classes. These circumstances reflected constructive, respectful behavior from the students. Overall, student conduct was exemplary and did not require disciplinary actions, such as detention or remarks in their school journals. The overall atmosphere was one of mutual respect amongst the students and between the students and the teacher.

\subsubsection{Relationship with the Teacher}

Teachers must ensure that students engage in one-to-one exercises for successful learning. Today, educators say that students are in the position of consumers of information and that students should play an active role in the environmental education process $[19,20]$. I ensured that the teacher's role was approached in a caring, supportive, friendly, firm, and equitable manner. In order to establish a collaborative environment with respect, kindness, and caring, a conscious effort was given. As a way of building a healthier relationship within the class, I took the opportunity to interact with students when I was not teaching. Regular feedback was shared with the students on their artwork, and I reviewed the progression of their assignments while observing their manners to get to know the students well. It was clear that these students valued our relationship as the school year came to a close. As a teacher, the interaction I had with these students was the most interactive I have ever had. I preferred to avoid making definitive comments about the environment and instead opted to provide students with knowledge, opportunities for alternative experiences, and a chance to learn from the experiences of others. The reason I chose this method was to prevent students from copying my own comments. However, I recognize that my choices of curriculum and questions for the students may have made my opinions clear. Overall, I hoped to be able to encourage rather than promote dialogue. I tried to encourage discussion rather than openly offering my thoughts to students.

\subsection{Curriculum Design}

Generally, it has been suggested in numerous research articles that students should develop a living relationship with nature prior to the request to conserve the environment; the subject of place-based art education based on guiding students to be naturally connected to nature. According to the researchers, teaching natural issues to students can be mindboggling and monotonous for them [21]. This step, in which the students participated in various nature-related activities, represented the process's climax. In this study, three units of the curriculum were designed, providing justification for the insertion of different tasks and artists, and debating on relevant problems. This curriculum was created to be given out during the post-test test. 


\subsubsection{Harmony}

Harmony can be identified as a key component of the place-based art curriculum since it has been identified as a significant principle of design and it has been known as a basic ecological concept in a place-based art curriculum [22]. The students learned different perspectives on art education, such as harmony, empathy, and care, throughout this unit of the place-based eco-art education curriculum. The students moved forward in the lesson to recap the elements of design in order to prepare them to engage with these understandings. Aside from that, they were encouraged to use a variety of different types of media. The students were mostly interested in learning how harmony can be used in the arts and other fields, including from an ecological standpoint. As an example, the students were given the task of identifying the connection between the artwork and elements of design and, at the same time, between fauna and flora, living species, and environmental systems. Graham (2007) depicts three critical components of environmental art education: transformative education, cultural journalism, and natural illustration. Nature illustration and cultural journalism were covered in this unit. In this unit, there were two projects: sketches of natural objects and garden planters. The main aim of this research was to stimulate the intentions of students regarding the natural environment and natural history illustrations, and the projects were mainly designed to cover those parts and the observation skills of students. This will enhance the rapport between the students and the environment, and also, the students will learn how to respond to environmental stimulation.

\subsubsection{Natural Illustrations}

Graham (2007), a well-known art education theorist, observed the historical background of the criticism of natural illustration to praise its benefits. Art educators were invited by Graham to revisit sketches and illustrations as they can promote love and care for the earth and the environment. Additionally, it is mentioned that students who have completed an environmental education program become conscious of the environment, empathize with nature, and draw strongly aesthetically valued pictures [23]. In this curriculum, the students started the lesson by reviewing the art of Vaco Baissac. Vaco was born in Mauritius in 1940. He studied art in Paris from 1964 to 1970. After he completed his studies, he went to Africa for 20 years. He returned to Mauritius in 1990 to continue his painting. Vaco has represented Mauritius at different exhibitions with his paintings of the island and its natural resources. His main motive in life is to show his "Creole" heritage through his paintings. His paintings feature natural landscapes, Mauritian culture, and flora and fauna. His inspiration is mostly drawn from his garden, the streets, the beach, and the people he meets, and he also shows the "dodo" through his paintings. The aim of introducing Vaco Baissac's painting to the students was to make them feel the beauty and nature of Mauritius and to be inspired by the local artists. The students were also introduced to the artist William Bartram, a natural illustrator who traveled through many countries to study and record the flora and fauna. Bartram is well known as an artist who works through his vigilant observations of nature; his paintings were unique in comparison to other art works at the time, and they clearly emphasized the capability factor; he wanted to capture the liveliness of his field of studies and his constant interactions with nature. As an explorer, Bartram discovered the value of learning the diversity of trees and plants for naturalists [24]. In order to enhance students' skills and abilities, including observation skills and drawing skills, thus enabling direct experience with the environment and forming a strong connection with nature, these illustrations were included in the curriculum. Bartram and Vaco represent the artists who demonstrated these behaviors through their cautious observations of the environment and their capability to detect the liveliness of their elements. However, the painting of Vaco Baissac is more abstract compared to Bartram, who included more details in his painting.

The class first watched an educational video on naturalists' nature to prepare them for the natural illustrations. These videos demonstrated a method for drawing plants creatively from students' live observations. The students went over a PowerPoint presentation about 
Vaco Baissac and William Bartram, including their biographical information and, most importantly, their paintings. During the presentation, it discussed the students' desire to depict the life of a natural plant through their own artwork. The students also attempted to paint the Vaco Baissac drawing. These methods and strategies exemplifed "harmony" with the environment. Then, the following step to consider was the relationship between science and art, which were two streams in the curriculum. As a first step, students must read books on nature studies. That is the way that scientists and artists study nature. The students teamed up together and then explained their views using a Venn diagram that reflected the differences in nature's studies through science and art, and the purpose was to identify the overlapping parts of science and art. Students stated the importance of observation for both streams, and it was highlighted. The students were instructed to carefully observe the natural objects they had chosen for drawing. See Figure 2. The students also talked about how art can be utilized to express an idea and can be used to embrace subjectivity and how science can be used for objectivity. The latter is described as art that has the power to connect feelings and thoughts.

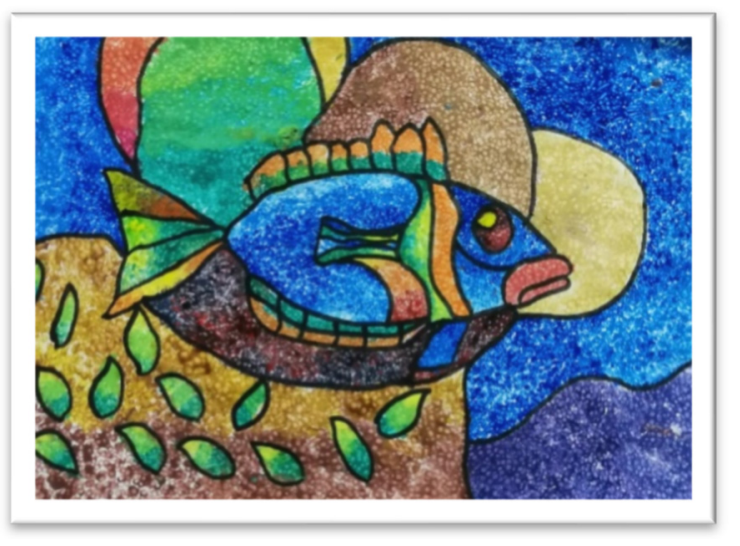

Figure 2. Student's painting pointillism (inspired by Vaco Baissac).

The key topic of the lesson was "harmony". At the initial stage, the students were asked to define their relationships with the term "harmony." Students explained it as music and peace, among other associations. Students were given standard definitions, synonyms, and a few meaningful sentences, including one for the term harmony. Then, the discussion was arranged to explain the role of harmony in different fields, including art, nature, the earth, racial relationships, politics, and music. When going through Vaco and Bartram's illustrations, the class analyzed how their illustrations demonstrated harmony. Students were given their definitions of what harmony is and of different harmonious relationships in their sketch pads. Later, the class began to participate in outdoor sketching on sketch pads. First, they visited the school's courtyard, filled with a garden. Then, they spread out with their sketch pads and started to sketch various natural objects around them. They also found natural objects such as leaves, bird feathers, flowers, and brought them to the class to finish their work. During the period given to observe the students, they had the chance to directly experience nature. See Figure 3. Furthermore, they conducted observations and studied real-life natural phenomena in order to gain firsthand experience for their drawings. The goal of this interaction was to make education meaningful since it links education to their lives in practice. In class, students had a few discussions and practiced drawing pictures with various media. As a first step, the students were exposed to various techniques and media. Because the techniques were similar to the techniques they already used to draw, they tended to come as natural skills. In addition, an art tutor, a member of the art club, visited the students and taught them how to draw plants. She incorporated and assisted students in learning how to carefully observe plants as they drew them. The art teacher was invited since she had experience and would be able to provide an additional perspective on the drawing. Aside from that, she was expected to inspire 
students with her enthusiasm for drawing plants, as well as her own views on how fine art can become a lifelong endeavor. The guest speaker session is a communal and important task in place-based education that brings a sense of community, relationship building, and life connections.
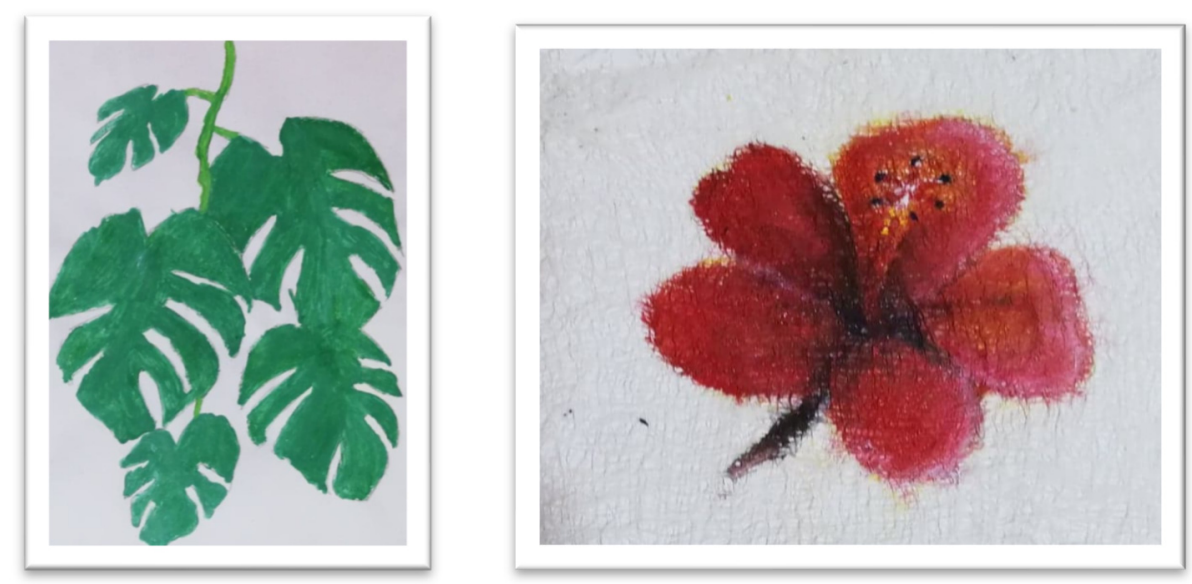

Figure 3. Students' nature drawing.

The students were compelled to utilize their paintings to share their ideas and feelings when they were creating their drawings. Students drew their ideas on a sketch pad to represent their own thoughts. They had several options to choose different media, such as chalk, pastels, charcoal, colored pencils, and markers, which were used as tools to represent the ecological objects they found in the yard of the school. The students were encouraged to decide on any method of drawing. Art media and line techniques were used to show ideas and feelings. Finally, the class reviewed the students' drawings through verbal analysis. Each student was allowed to display their sketch on the critique wall and the rest of the classmates opened up the discussion to express, analyze, interpret, or evaluate the displayed art. The same opportunity was given to the next student after the discussion of the first artwork. The selected elements of designs and techniques by the students were explained in the classroom by the students and, furthermore, how they associated themselves with the thoughts they were attempting to convey. The lesson was concluded by stating how their drawings displayed harmony. The activities took place in nature's drawings, and students' development was accelerated, particularly in their drawing and observation skills, in order to examine and communicate philosophies about nature. This lesson was the initial launch of supporting students in developing awareness of the natural world and having supplementary experiences with nature, to protect it, and also to step into the natural environment with an understanding of how harmony is possible within nature.

\subsubsection{Place}

Soon after learning how harmony works in art and the real natural world, in the next stage, students began to discover the importance of places. The place contributes to nature being a key positive result in environmental education programs, outdoor education programs, and even early childhood education as a whole [25]. Place investigation is considered to be a basic step in a place-based education program as it offers a physical environment for inspecting the association and diversity of social, ecological, and aesthetic notions. As a result of that, it was required to demonstrate the usefulness and response rate of art to the social and ecological problems of a place. The supposed outcome of this unit was to enhance the students' understanding, including the ability of art to share views about a place, and, additionally, how art is capable of foreseeing different realities. At the beginning of this unit, students were encouraged to see their connection with a place and to express the same through a drawing. When they fully grasped the concept, they 
were asked to consider the future of their place in society or the community through their drawings. These two projects were essential for the students to know how a place played an important role in the students' lives, and they were concerned about the actions that they can take to impact the place.

\subsubsection{A Special Place}

The lesson began by studying the art of the local modern artist, Róisín Curé. Roisin grew up in the west of Ireland. Roisin used to visit Mauritius several times. Normally, Róisín Curé drew whenever she could recall or capture the memories, her thoughts and feelings that made her realize who she is, and the world that she lives in. Even though she had been drawing in the proverbial world for some time, she only discovered urban sketching in 2012. While on a sabbatical in Mauritius, she took to the streets, beaches, and countryside of Mauritius and discovered the joy and peace of quiet sketching and the fun of meeting the public. She drew or painted nearly every day and saw the country in terms of capturing it in line and color. Generally, most of her drawings illustrated local and recognizable locations within our country, including the Botanical Garden of Pamplemousses, Triolet Temple, giant lilies, fishing boats at Trou aux Biches, and the market stall at Triolet. In one of her Trou-aux-Biches beach paintings, Róisín Curé mentioned, "Yesterday I saw some beautiful beach leaves that I wanted to paint. I did try to paint and capture the liveliness; I had been stuck in front of the beach because of its magical feel." Despite the fact that these paintings are nostalgic, she claims that they are appropriate for students. Three outstanding examples were her paintings the market stall of Triolet, Trou aux Biches, and the giant lilies in the Botanical Garden, Pamplemousses, which were so familiar to the students. The students were stunned by the painting because half of the students lived nearby in the north. Roisin manages to discover the beauty of our country's landscape. Her art is most relevant to this subject program in the location given because she has been recognized as an artist who has been actively involved in the community. Further, her drawings directly address our society and reveal a pure visualization of the place.

When referring to Róisín Curé's art, the class reviewed the different criteria of her art, which were subject matter, style of painting, and her vision of communication through discussion. The themes of these paintings were extremely familiar to the students, and they actively responded soon after recognizing the location. The majority of them were ecstatic about communicating their connection to the places she had depicted in her drawings. The quote below is from Rosin, and it describes how she assisted students in incorporating the relationship with the place into their paintings. "Stuff happens when I'm out sketching," one of the quotes reads. "It can be something that words can't describe, like the serenity I feel surrounded by the sound of birds, some beautiful leaves, the places and people I visit in Mauritius that I have always wanted to paint. There was something so magical about them. The colours, the hues I try to bring my world to life in my sketches and the stories that go with them".

In the next class, the students started to study their relationships with places. Roisin's paintings of the Botanical Garden of Pamplemousses, the market stalls of Triolet, and Trou aux Biches were shown using the projector. The aim of showing these paintings to the students was to make them connect with the place. The students were so amazed and excited by the painting. The students expressed their thoughts on the painting and described their experiences with it.

Some of Róisín Curé's quotes in her paintings helped students understand their relationship with the place, as well as the possibility of how the relationship with the place might be illustrated in her drawings. One of these quotes was: "I really love when I hear some really meaningful stories connected with the places I paint". After studying the works of Róisín Curé and exploring how art can reveal ideas about the place, the students concluded the lesson by updating their definitions of the place. The word "place" is a common and recognizable term for students and, as a result, students will come up with their own visions of the place. The opportunity was given to students to share their 
views with other students in the class. This method has lots of advantages, which include openness, the ability to lead discussions on issues and limitations, emotional connections, and community relationships. The students sketched their favorite place to visit and how they feel when they are alone in that place. It focused on the connection between the students' lives and specific locations through such an exercise. Students were encouraged to choose a specific location that they had visited once or more in order to reveal a close and ongoing connection. It was slightly difficult if they chose a place that they visited once on a vacation.

The ultimate expectation was for students to replicate a meaningful experience of the place. In addition, this may be a greater foundation and could be extended to provide a connection with the natural world. Then, all the students were advised to design a painting that illustrates their relationship with the selected place. Reflections on places. Students looked at the concepts and techniques of art that would be necessary to accurately reflect the place and its relationship with it. Lately, the students have come up with a few examples of paintings done by Vincent Van Gogh, Róisín Curé, and more. They also explained the various painting techniques and styles used in the paintings of those artists. Then, the students were allowed to design their painting style to use in their project while experimenting with various techniques and styles used by the examples of paintings. These activities urged them to either embrace one of these famous styles or use their own method. As a result, students determined what style of suit they should wear and began sketching it on their sketch pad.

The students began to get involved in developing their paintings in the next lesson. As the first step, thumbnail sketches were created on the sketch pad of a favorite place they often went to in nature. They were given instructions to work according to the style they preferred or adapted to the place in the previous lesson. They sketched the locations based on their memories and relationships with the locations. Since they were drawn from memory, the paintings tended to be less realistic. First, students visualized the relationship with the place and added more expression to the paintings. The unit also consisted of a portion of the class where they discussed their paintings in the same way as the drawings of nature. Based on the simple method of explaining, examining, interpreting, and reviewing their work, the classmates had a discussion and received feedback. Moreover, the students explained their painting, showing the relationship with the selected place and how it was demonstrated in the painting. Also, students explored their preferences for topics, painting techniques, styles, and colors, in particular. Through this project, the students began to be concerned about the place, the relationship between individuals and the place, and the rapport with specific places. The purpose of this study was to develop a much deeper and enhanced relationship between students and the connection to the places where they live.

\subsubsection{Alternatives to Places}

The second section of the unit began with a task where the students were requested to map their communities. Students were divided into 3-4 groups to map the important places within their work community. Also, the groups were informed to keep their emphasis on specific locations. These maps were representations of important places, not the exact map, but the approximate vicinity of the community. Then, there was a discussion about the specific locations on the maps and the possible reasons for their comprehensive inclusion. Some mentioned, "I have a garden area in my locality and there are many trees. People always sit there and enjoy chatting with their friends". Others mentioned, "they have a river and around five monkeys are living there. I saw them when they were crossing the road to go to the side river". The activity map provided guidance for students to understand the most critical impression of the society and reflect on the community of the environment. Then, each student was told to select a particular area from the cultural map that had intense feelings for them and that they would later discuss it in a drawing. At the end of the lesson, the students reflected on their relationship with the chosen area on their sketch pad. The class moved to studying the art of Markus Vesper, an environmental 
artist. He is known for his paintings describing environmental issues and their effects. Generally, most of his paintings represent the consequences of human actions that led to global warming. These detailed paintings have also given us apocalyptic visions of our future where human evolution is in decline. Imagination is not only allowed to envision positive alternatives, but it may also bring us to the severity of our actual conditions. Such imaginations inspire all to make a prominent change. The majority of Markus Vesper's paintings are works of imagination in which he sees negative alternatives or a condition. The majority of his paintings depict a wacky, out-of-the-box state of affairs. As previously stated, these artworks provide a forewarning about the negative consequences of modern society's bad habits and lead to new action plans. In the previous lesson about the place, activities were given to students to take a precise place that they thought was significant to their community. The activity concluded by giving them the task of creating an artwork related to the chosen place for them. Keeping this in mind, a PowerPoint presentation on Markus Vesper's art was shown that included his paintings, the symbols of the place, and the philosophies they communicated.

To enhance students' understanding of potential ways of creating a sustainable future for the community, a discussion was conducted in the presence of four senior students from the DUKE of Edinburgh. They mainly elucidated green initiatives, including environmentally friendly construction methods, renewable energy sources, organic food production, green gas emission, and protecting the land. The discussion helped students to anticipate a better future that could happen if the explained initiatives were widely implemented. The presenters also assisted students in visualizing other ecological changes. Finally, students finished an assignment comprising a picture of "how your preferred place has been handled". "How do you see the future of your own place? Why? How do you want to see the future of your place?" Based on the answers they received for each question, the students were encouraged to place the ideas on their sketch pads, "The future of their place". When the students had finished their journal entries, they volunteered their sketch pad. A brief discussion about our hopes for our community was held in front of the class. Doing such classroom activities allowed students to excel in their imaginations while also exercising for a better future in their community. Some boys implemented some ecologically responsible measures in their communities as responsible citizens and some students followed Markus Vesper's example of devastating realities to provide an alarm about the results of their actions. See Figure 4.

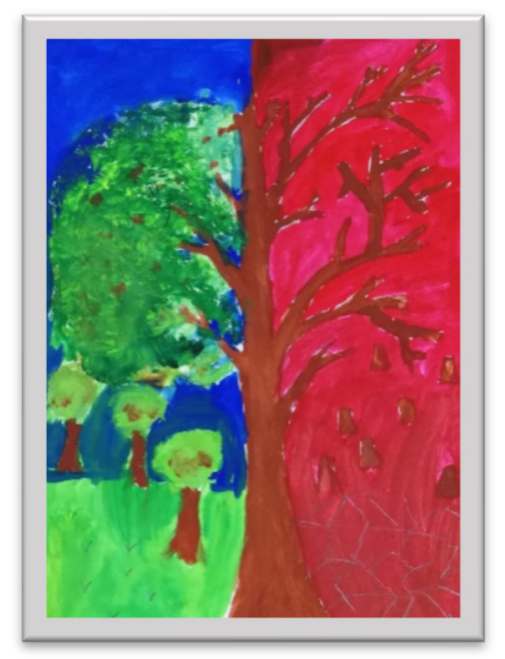

Figure 4. Student's future of place drawing.

Finally, the unit concluded with an assessment of the areas covered and a written response describing their artwork. The students explained the place they had chosen, the future predictions they had imagined as an alternative, and why they chose to represent 
the alternative. During the assessment, the written notes, including additional information, were shared with the entire class, and other students were asked to explain, analyze, understand, or assess their classmates' paintings. Later, the complete artworks were displayed in the school corridor with students' writing designed to accompany their works.

After the few sessions explained, the student demonstrated the relationship between place and on the sketch pad as the final assessing activity of the unit. This unit was adapted for a place-based art pedagogy in which the boys were interested in local place and environmental issues. During the sessions, students were invited to choose places they had previously encountered, to explore them, and to project complex ecological realities on the places that form the foundation of their communities. Opportunities to display their artworks and writings in the school corridor provided them with a platform to bring their ideas outside of the classroom. This step was the initial step of their process. The next unit stimulated the students to take ecological actions for transformation.

\subsubsection{Transformation}

By observing the environment, the students' progress to a final unit on transformation, a unit outlined to assist the students in steadily and imaginatively commuting into their environment. Adherents to the views of the ecological imagination, students should evolve an affiliation with the natural world and with the place prior to safeguarding it. The previous units were built to promote connections with the natural world, places, and the community, as well as to spread perceptions of ecological problems, and students were now focusing on environmental change.

Graham (2007) defined the transformative component as the possession of a transformative education within an important educational setting. It can be identified as the most important factor in the place-based pedagogy in this unit as it outlines a move from developing connections to influencing change. In this unit, there was a requirement to obtain the following interpretation: social and ecological matters can be countered by art; art can convert emotions, space, feelings, attitudes, and communities; and artists are inventive and, as a result of being inventive, artists can utilize any kind of material. Students created eco-artworks from debris and leftovers, such as plastic bottles, to attract students with mastery.

\subsubsection{Eco-Artworks}

The lesson started with an introduction to a variety of eco-artists through a PowerPoint presentation, including Baisa Irland, Lynne Hull, and Steven Siegel. To address students environmental concerns, we considered a variety of approaches. These approaches were about discussing and, endearingly, building ecological abodes through art. Students were able to form new relationships as a result of the eco-artists' efforts. Soon, the students began to make connections with the efforts of others through their artwork. The students also began an extensive inspection of the eco-art of Steven Siegel, where the artist utilized consumer debris in site-specific sculptures. The site contains the work of an artist who used consumer waste to create massive, site-specific sculptures. His body of work comprised a pile-up set, large outdoor sculptures collected from piled and decayed newspapers, and large outdoor sculptures collected from consumer waste.

The work causes awareness of the massive amount of consumer waste that exists, prompting us to consider the fate of such waste and how our lifestyle choices may contribute to its accumulation. The students considered the transformation of materials, the transformation of outdoor space, the transformation of art over time, and the transformation of ecological attitudes. Students concluded, based on prior experience, that the power of art in verbal journals has transformative power.

To be innovative, the students were requested to gather debris and waste items, such as plastic bottles, newspapers, and aluminum cans, for the artwork. Additionally, students 
had the opportunity to consider and get ideas from their colleagues and share their ideas with each other and outline the pad.

Among their colleagues, they thought about how their drawings could be transformative as they received their ideas from prior learning and experience. First, they chose the design, and then, they confirmed the sketched drawing for acceptance. Many students came up with the idea of creating an eco-artwork out of plastic bottles. The plan was to come up with a design with vertical hanging plastic in the yard by joining a string of plastic PET bottles together with a strong cord and fixing them to a wall.

By looking at the sketch drawing plan, there were a lot of constraints that were needed for moderation in the areas of safety concerns, construction methods, and in the materials. Finally, after all the work, the sketch drawing plan designs were approved, and the students started to collect different debris and waste materials to design the ecoartworks. Additionally, students received advice and help with tools and materials from the design and technology department.

Finally, after completing the assembly of their eco-artworks, the students replanted their plants for their eco-art project and received permission from the school to display and demonstrate the project. Furthermore, students thought about a place where the project could be kept and displayed for all the students and staff in the school. Many students agreed to keep the project in the assembly area so that it could be seen by as many students as possible. Students also came up with a statement in the assembly area for the audience, stating the fact that waste and debris could be repurposed. Finally, when concluding the unit, with prior experience and knowledge, students asked the audience about the artwork, and they used the designed pad to get the responses from the audience while stating their responses. This led many students to learn about local ecological issues, to be creative with artistic tools, to focus on how art has the ability to transform, to be unique and to think differently, and to adapt to the ecological concerns and impact of other students and teachers at their school.

In the comments, it was indicated that the teachers, administrators, and students stated that the project was informally briefed and explained in detail to all of them. Furthermore, many students who were not in the same class responded enthusiastically about the work and stated that they could design and create related artwork that is similar, and those students signed up for the class and were eager to join the art club.

\subsection{Activities in the Eco-Art Place-Based Education Program}

\subsubsection{Drawing in the Schoolyard}

It is believed that the use of artistic expression for environmental consciousness will cultivate enthusiasm, as students' love for beauty makes it essential to see and appreciate it [26]. The activity was set up in the school yard to make the students care and love their environment, and the students were there with their pencils and sketch pads. First and foremost, all of them walked around the yard to explore the surroundings. It seemed like interesting work for the students, and they were advised to recreate the scenery on their sketch pads. Some chose a suitable place to sit, others remained standing and started to draw leafless trees, grass, or rocks. After they spent 35 min outside, a few people went back in the classroom. A few of them, nearly a third of the class, wanted to stay outside. They were hesitant to go inside, so one student asked, "Can we please stay for a few minutes and also take the other class?" This outdoor activity was well received by the students. Then, after a few minutes, the rest of the students also came back to the class and started to draw the indoor plants. Therefore, for the rest of the minutes left, they went back to the classroom to draw indoor plants.

\subsubsection{Walking in Nature}

If we are to examine pedagogy and practices more closely, as suggested by Barrable, rather than focusing solely on contact, a set of specific objectives must be defined. The goal of her paper was to place natural relations at the core of the practice of natural settings 
and to open the way for more comprehensive methodologies to be used to determine what works in outdoor settings [27]. Following Barrable's methodologies, the students again walked to the back of the school to look for more natural objects to illustrate in their drawings. When outdoors, several students walked along the paths and preferred to study their surroundings and gather natural objects. When the boys were all together, they talked about how they could use their time outside to observe and collect interesting objects to draw from the nature that surrounded them. After the instruction session, the students walked together and found natural objects of their interest. When returning to the classroom, all of them carried at least one object to draw.

\subsubsection{Drawing Nature}

Students brought in a range of items, including small branches, rocks, flowers, and leaves. They were encouraged to observe their objects closely while they engaged in drawing a particular object on their sketch pads. One student, who was most interested in drawing cars and cartoonish characters, was having difficulty drawing natural objects. Since the lesson was mainly focused on drawing by observation, the student was allowed to draw an observed person as a part of nature in order to ease his frustration with drawing natural objects. Therefore, it was recommended to sketch his friend who was seated next to him. The student drew his friend with a leaf in his hand. Some students preferred to use bigger natural objects or more than one object to fill in the composition, although a few students used the same objects and drew different angles on the objects several times. The majority of the participants chose an abstract background for their drawings that included solid colors and color gradations. The rest were demonstrated in a realistic context. Many students were attentive to the texture when depicting the drawing. Several students struggled to accurately depict the object's proportions. They were free to draw their objects.

\subsubsection{Growing Plants}

Students planted strawberry plants in the school garden, which they then transferred to their Eco-Art project. All were very keen on planting their own plants. Few people were certain how much water they should use for their plants. Even after being told to check the soil, some students overwatered the plants. The soil seemed to be submerged in about an inch of water. Meanwhile, someone had watered other people's plants without their permission, resulting in overwatering. On the following day, students came and asked whether they could water their plants. Every morning, a student came in and asked me to look at his plant. Two weeks later, it appeared that most plants had started to grow. From the beginning, they were all concerned and excited about what their plants would look like when they grew up. Unfortunately, some plants did not grow properly due to overwatering. Those students requested that they be replanted, and those plants gradually began to grow well as well. When one student saw his plant growing, he shouted and said, "Look, look, it is growing! I won't let it die now!", as he walked out of the plant area with a huge smile. As the plants started to grow, they quickly moved to their eco-art project. On two separate occasions, students requested a larger space for their plants. Most plants grew up to four inches higher before stopping. The students were disappointed when they noticed that their plants did not grow well. They felt disappointed since they had been overwatering and, therefore, the plants were not flourishing. Once upon a time, the students were very excited about transferring their plants once they completed the eco-art Project. At the end of the program, a few students commented that their plant was doing well.

\subsubsection{Painting a Special Place}

This time, students chose a place where they go often to be alone. The students were shown, for example, the Róisn Curé painting and her quotes. "Is it okay if we choose an indoor location?" a student inquired. It was acceptable in this activity whether the location 
was indoors or outdoors. These areas included reservoirs, ponds, gardens, backyards, bedrooms, a living room, a pond, and a big rock. The majority of the locations they had chosen were outdoors. The majority of the paintings lacked human figures, but a few inserted themselves into the landscape. The majority of the students chose the watercolor painting style to depict their paintings in various other painting styles and techniques, while other students selected the acrylic style. In a nutshell, the finished painting used naturalistic colors and depicted natural settings. In the evaluation, students described the locations as places to rest, relax, or have fun.

\subsubsection{Visualizing the Future of Their Place}

When students connected with Markus Vesper's art, some had minor difficulties understanding his works. The students were given an explanation about his work. After the explanation, the students responded positively. One student said, "I love his art!". Another student said, "He is the first artist I really felt connected with." A few others made comments on how they were attracted to his art. Then, we started to make thumbnail sketches of an alternative place. During the activity, people commented on Markus Vesper's apocalyptic approach. Apart from drawing a better future of a place like others do, they were advised to use their traditional apocalyptic depictions of their city. Based on the approach discussed, a few of them drew their city with flooded houses and towers where they saw only the roof tops, and one other student drew a portrait of the city with floating viruses in the air. Many of the students, in particular, appeared to be focused on a better future rather than an apocalyptic outlook. In the students' imaginations, parking slots that were ideal were replaced with gardens and parks in their selected community; houses utilized new energy sources, such as solar power. Cities were modernized with locally produced organic produce restaurants and grocery stores; sidewalks, bike lanes, nature trails, and cycling stalls, minimizing our reliance on automobiles; roof gardens on urban structures; energy-efficient streetlight bulbs; small shops offering items made from recycled materials; and planted trees. It was an eco-friendly setting and readily available recycling bins could be found around the city, and it appeared that wildlife and birds lived happily. See Figure 5.
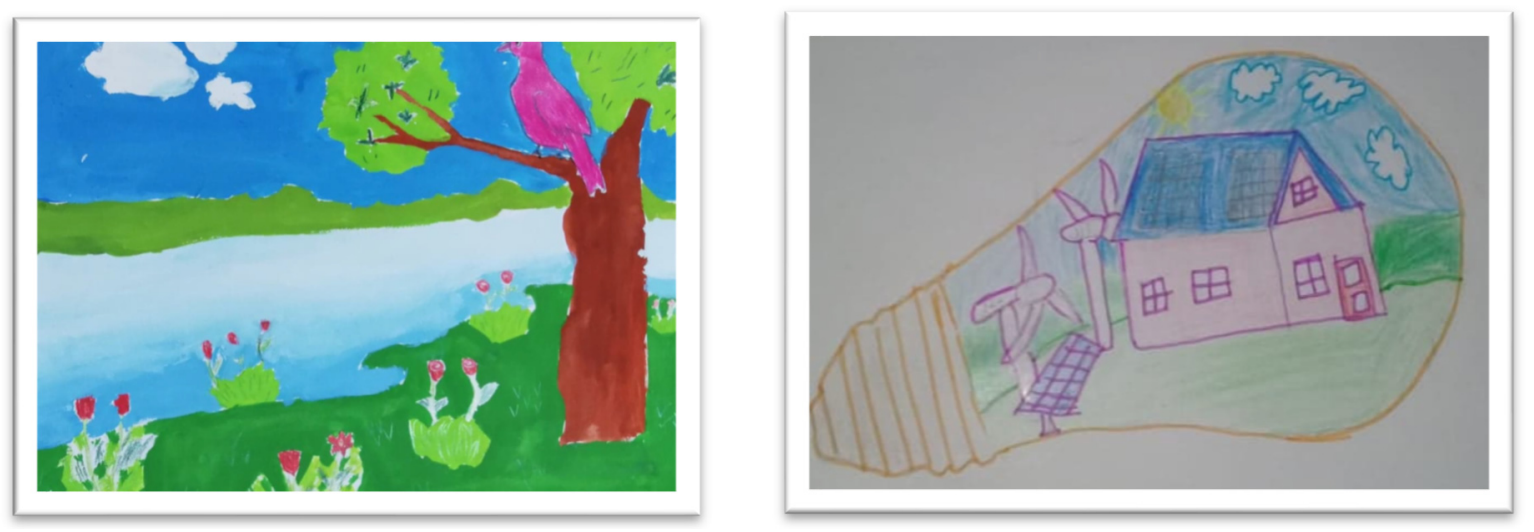

Figure 5. Picture of students' special place.

\subsubsection{Visiting the Nature Trail}

This class and one of my grade 13 classes went on an educational tour to visit a nature park at "Bras D'eau Mauritius" and walk along the path. The students were greeted by one the tour guides while we were at the nature park. He directed us to the path. He also provided the students with information about the trees and their importance. He also talked about environmental issues and told the students not to throw trash. The students were focused and attentively listened and infrequently questioned relevant things to clarify. The visit lasted an hour and a half. After the visit to nature, the students had lunch at the 
beach. They also played football with their friends. Some walked in the sand, and they played with the sand. Some of the students sat and admired the sea and the sunlight. One student saw a plastic bottle near where he was sitting, and he immediately took the plastic bottle and put it in the dustbin. Even once the students came back to the school, they felt reluctant to get off the bus; also, all the students conveyed their gratitude to the bus driver, their friends, and the teachers. Before leaving, some students said we should go there more often; it was a nice trip, and it was so peaceful and beautiful.

\subsubsection{Creating Eco-Artworks}

The research of Fragkoulis and Koutsoukos explains a unique teaching approach using two works of art in environmental education, making products for teaching conservation, and re-using more experiential, participatory, and original work [28]. The purpose of their project was to enable students to discover and learn about environmental issues through art and to develop their skills, including collaborative learning, teamwork, dialogue, and exchange of views when working in groups. In this study, the students also formed groups to produce eco-artwork and experimented with the use of a range of recycled materials, such as plastic. They created a vertical hanging plant garden by stringing plastic PET bottles together with strong cord and securing them to a wall built with wood frame. See Figure 6. As they worked, a few students showed anxiety about storing their project because they were afraid that students in one of the other classes could play with it. Students felt slightly nervous to display their project to the school once they were done with the project. All of them were keen about the date and the options for displaying the project. Assembly areas were selected by the majority of students to display their project.
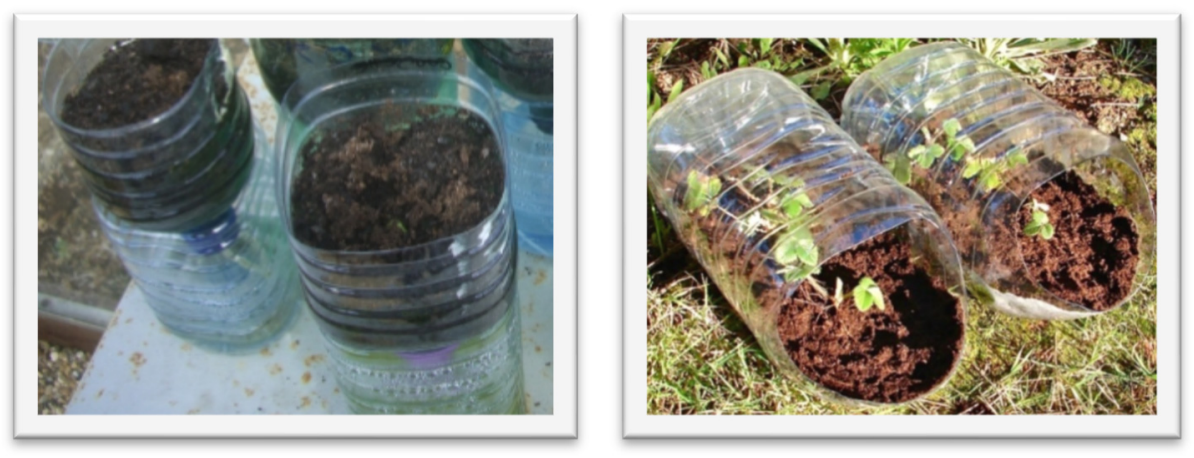

Figure 6. Pictures of transporting the students' plants in their eco-art project.

\subsection{The Students' Pro Environmental Behavior}

The student's environmental behavior was evaluated using the numbers 1, 2, 4, 5, 8 , and 10. Question items 3, 6, 7, and 9 were used to determine the children's antienvironmental attitudes. Through the activities of growing plants, students had the opportunity to consider design connections between form and function as the planters were inspired by the form of their plant and responded to the needs of their plant. However, to determine students' ecological paradigms (pro-environmental orientations), the New Ecological Paradigm (NEP) scale for children was administered with students both preand post-test. It provided an overall score from 10 to 50, indicating their position on a continuum between an anthropocentric and eco-centric orientation, as well as mean scores from 1 to 5 . Students were given the NEP questionnaire pre- and post-survey. The New Ecological Model (NEP) scale was updated in this questionnaire. Students between the ages of 12 and 14 were given the revised NEP Scale. This scale was more appropriate for the students who were between 12 to 14 years old than the adult student, having appropriately developed the language and reduced the number of scale items. The NEP scale is a 5-point Likert scale that ranges from 1 (strongly disagree) to 5 (strongly agree). The total scale score ranges from 10 to 50 , with 10 representing support for the dominant social paradigm (DSP) and 50 representing support for the NEP. A 30 denotes a balanced response. 
The questionnaire examined and then sorted the participating 672 participants for a two-year study. This questionnaire has been determined to be the most suitable for students aged 10 to 14 . The three stages of this analysis are all closely related facets of students' pro-environmental attitudes: nature's rights, the eco-crisis, and human exceptionalism. Both aspects are connected with the belief that humans are the exception to nature's laws. Furthermore, they discovered that an overall score can be assigned to reflect a student's viewpoint on a scale ranging from anthropocentric to eco-centric orientation.

The aim of introducing the questionnaire was to learn how the eco-art and place-based curriculum influenced the empathy of the students towards the environment through these activities. The findings presented an average score of students' environmental orientations to the New Ecological Paradigm (NEP), as well as information on their attitudes toward nature's rights, the eco-crisis, and human exceptionalism. The survey data were tabulated and translated using descriptive statistics to include the frequency distribution of each item. Next, the mean was conducted to ascertain whether the change between pre and post test scores was statistically significant.

The means and standard deviation for both pre- and post-test are found in Table 1.

Table 1. Means and standard deviation result for the NEP $(n=25)$.

\begin{tabular}{|c|c|c|c|c|}
\hline \multirow[b]{2}{*}{ Scale Item } & \multicolumn{2}{|c|}{ Pre-Test } & \multicolumn{2}{|c|}{ Post-Test } \\
\hline & Mean & $\begin{array}{c}\text { std. } \\
\text { Deviation }\end{array}$ & Mean & $\begin{array}{l}\text { std. } \\
\text { Deviation }\end{array}$ \\
\hline $\begin{array}{l}\text { 1. Animals and trees have the same right as } \\
\text { humans to live on this earth. }\end{array}$ & 1.48 & 0.653 & 1.68 & 0.988 \\
\hline 2. A larger number of people live on the earth. & 2.72 & 1.06 & 3.80 & 1.32 \\
\hline 3. Humans on the earth are destroying the earth. & 2.52 & 1.25 & 2.40 & 1.08 \\
\hline $\begin{array}{l}\text { 4. Humans should conform to nature and the rule } \\
\text { of nature. }\end{array}$ & 1.48 & 0.653 & 1.72 & 1.02 \\
\hline $\begin{array}{l}\text { 5. The people should receive negative } \\
\text { consequences for damaging nature. }\end{array}$ & 1.68 & 0.802 & 1.92 & 1.52 \\
\hline $\begin{array}{l}\text { 6. Nature has enough capacity to handle the bad } \\
\text { impact from the modern lifestyle of humans. }\end{array}$ & 2.76 & 1.17 & 3.28 & 1.23 \\
\hline 7. Humans try to handle things over nature. & 3.16 & 0.927 & 3.88 & 1.49 \\
\hline 8. Human behavior hardly impacts nature. & 1.72 & 0.737 & 2.32 & 1.14 \\
\hline $\begin{array}{l}\text { 9. Humans understand the way that nature } \\
\text { handles and control things. }\end{array}$ & 2.36 & 1.15 & 2.64 & 1.03 \\
\hline $\begin{array}{l}\text { 10. If humans have not changed, they have to face } \\
\text { the negative impact on the environment. }\end{array}$ & 1.56 & 0.821 & 1.92 & 1.18 \\
\hline
\end{tabular}

When comparing the post-test and pre-test mean values, the researchers identified that the mean value decreased for the statement "Humans on the earth are destroying the earth". The mean value for the pre-test for the above-mentioned statement was 2.52, which decreased to 2.40 in the post-test. However, the mean value for the first statement called "Animals and trees have a similar right to humans to live on this earth" increased in the post-test slightly compared to the pre-test, as the pre survey mean value was 1.48 and post survey mean value was 1.68 , mean difference of 0.2 . The increment in the positive attitudes of the students was related to the statement "A larger number of people live on the earth". The mean value for the pre survey was 2.72 and the post survey was 3.80 . Also, the students' positive attitudes related to items 4 and 5 increased according to the mean value of the pre-survey and the post-survey, namely, "Humans should conform to nature and its rules" and "People must suffer the consequences of nature." Moreover, strong improvements can be seen in the mean value of the pre-survey and post-survey results of "Humans try to handle things in nature" (pre-test mean value was 3.16; post-test mean value was 3.88) and "Human behavior hardly impacts nature" (pre-test mean value was 1.72; post-test mean value was 2.32). Students' responses showed an improvement in the 10th question item, which was "If humans have not changed, they have to face the negative 
impact on the environment" with a mean difference of 0.36 between the surveys. The mean values of the pre-survey highlighted the pro-ecological perspective view of the students in one semester. The post-test test score indicates a positive improvement in the students' views on the pro-ecological point of view.

\section{Discussion and Conclusions}

Students shared their enthusiasm for the art club program. Moreover, in their second year, students admitted that this was their favorite lecture. They expressed that they enjoyed the class. Staff also echoed these comments. The students frequently expressed a desire to attend the classes. They frequently took their sketch pads home on weekends and admitted that they were willing to clean up after the session. Furthermore, they had a strong desire to participate in more and more experiential activities. Students were given positive feedback on projects and activities in positive terms. Students also used words such as "fun", "interesting", "cool", "nice", and "neat" to express their experience gained through the class activities. Even during class, students freely commented on their experiences with specific projects, describing how much they enjoyed them. Unfortunately, a few students went through some frustration during the course and the activities. However, they are managing to catch up gradually. The overall response from the class and the project was positive. One student expressed his delight, saying, "It's fun." The information gathered through interviews and drawing activities aided in understanding and comparing the program's impact, as well as increasing empathy for the environment. The curriculum designed allowed the students to demonstrate a considerable improvement in ecological awareness over the year. They increased their awareness of their relationship with the environment, broadened their perception of nature, and gained various insights into the ecological crisis, allowing them to accept and make a change. The improvements in awareness were identified through these activities. Terms like "realized", "awakened my eyes", and variations, such as "eyecatcher" and "opened my eyes", were used to describe how this experience changed their awareness over the course of a year. These terms and phrases gave a clear indication of how the students saw the world and the environment in a new way and connected them with the experience. Students' feedback indicated that through the program, they received a greater awareness of the benefits of nature. The creation of this awareness had the greatest impact on activities such as nature walks and successive nature drawings. One student's explanation said that when he was drawing the plant, the close observation helped him to notice things he had not noticed before, and he mentioned that he was surprised by his new findings. Another student described the amazing moment he went through once he saw the plants in his grandparents' garden. Students improved their observation skills and stimulated concern about the other wonders in nature. Some students reported how the class helped them to become more aware of the environment and develop positive attitudes toward it. "What we learned about nature [the environment] opened my eyes, and I realized I could be optimistic about things," said one student. Moreover, he explained how he responded to nature before the course. He was not a person who paid much attention to the environment, and most of his thoughts were negative, such as pollution, waste, and his commitment to the environment. Similarly, another student said, "I believe that wherever we go, we are inspired to interact with nature, connect with life, the things we do." Moreover, he explained that, "Even though we know that the earth is highly polluted, I have realized that every place is not like that." His response makes sense: that not every place on the planet is polluted, and it made him realize that there are more beautiful places on the planet. In addition, the painting activity was dedicated to painting a specific location.

According to the findings of these data, students demonstrated empathy for the environment until the end of the program. Because empathy occurred internally, evidence of it must be found through students' behaviors and reflections. The care they have for nature, awareness, and the acceptance of responsibility towards the environment emphasize the empathy of the students. In a nutshell, it appeared that students advanced 
in their level of empathy for the environment and gained extensive ecological awareness. They also demonstrated pro-environmental behavior. As a result, children's perceptions of "the greater number of people living on the earth" may be used to justify changing environmental factors. However, the researchers disregarded the responses, "Human behavior hardly impacts nature" and "If humans do not change, they have to face a negative impact on the environment." Though these question items have nothing to do with the environmental crisis, they are the most important things (curriculums) that students learn in the classroom. The survey results improved the overall perception of curriculum development and implementation. Therefore, it is easier to implement the necessary changes to the overall subject area than to make changes to specific concepts. The sample size of this study was relatively small at 25, and the test results were significant. Wilkerson and Olsen explained the current research's misunderstandings about significant test results and interpretation of significant test results. The literature provides an opposing viewpoint on the significance of the test result and its use in social science. All these studies explain that a larger sample size can enhance the confidence level of the researcher and trust related to the investigation and the result of the study. However, the same level of confidence and trust cannot be implemented among researchers through an investigation with smaller sample sizes. It is difficult to understand the behavior related to the sample size. Mathematical approaches related to the significance of the tests explained that the confidence level related to the smaller sample size had been lost as the researcher took more detailed action than in the larger sample size to get the equivalent level of statistical significance. The statistical significance of this investigation was not weakened as it chose a smaller sample size based on the explanation of the early literature. Qualitative data highlighted that the improvement of the students in the ecological aspect is related to the view of the eco-crisis, which is important in the conclusion. The pre- and post-survey results of the survey explained the increase in the students' test scores.

The place-based art curriculum's distinct history, community, and culture were designed to allow students' ecological creativity to be thought about and acted upon. This will create a caring relationship with place by helping the students to find the meaningful essence of Mother Nature, by permitting and investigating visual arts, and also by encouraging unique thinking techniques to evolve into a variety of different suggestions of negative environmental impacts through art [29]. Prior experience with artwork was used to help the students identify with the natural world by expressing the natural world, which consists of all of the plants, animals, and other living organisms in nature. These tasks were competent in motivating and inspiring a connection with the earth. Since the students had prior experience and knowledge of the roles and the characters in their existing human lives, the students had the chance to increase their fondness for those places and reinforce the values in their relationships with those places. As students envision a better future in their community centers and a better understanding of the ecological beginnings that have already begun in their community centers, students prefer to let go of their fascination with formulating better ecological perspectives. Students gained experience posing the placement of their interest in work for the commitment for ecological change because they had the opportunity to engage in art-making. This is supported by the research of Yeşilyurt, who stated that many of the students empathized with nature and placed it in the role of nature themselves. This indicates that students fully accept the behavior. In addition, the engagement of students with nature and learning through doing and living has made it easier for students to engage with nature and has allowed students to build an ecological outlook [30].

Author Contributions: Conceptualization, A.S. and C.B.; formal analysis, A.S.; investigation, A.S.; resources, A.S.; data curation, A.S.; C.B.; writing—original draft preparation, A.S.; writing—review and editing, A.S.; visualization, C.B.; supervision, A.S. All authors have read and agreed to the published version of the manuscript.

Funding: This research received no external funding. 
Institutional Review Board Statement: Not applicable.

Informed Consent Statement: Informed consent was obtained from all subjects involved in the study.

Data Availability Statement: Not applicable.

Conflicts of Interest: The authors declare no conflict of interest.

\section{References}

1. Orr, D.W. The coming biophilia revolution. Earth Isl. J. 1994, 9, 38-40.

2. Kışoğlu, M.; Gürbüz, H.; Sülün, A.; Alaş, A.; Erkol, M. Environmental literacy and evaluation of studies conducted on environmental literacy in Turkey. Int. Online J. Educ. Sci. 2010, 2, 772-791.

3. Ogueri, C.A. The Need for Environmental Education in Secondary Education Level in Nigeria: Problems and Challenges; Department of Environmental Technology and Social Studies, Roskilde University: Roskilde, Denmark, 2004.

4. Chawla, L. The ecology of environmental awareness and action. In Critical International Perspectives on Participation in Environmental and Health Education; Jensen, B.B., Reid, A., Eds.; Danish University Press: Copenhagen, Denmark, 2006.

5. Franklin, M. The esthetic attitude and empathy: A point of convergence. Am. J. Art Ther. 1990, 29, 42-48.

6. Koss, J. On the limits of empathy. Art Bull. 2006, 88, 139-157. [CrossRef]

7. Forbes, I. Rainy Night Krispy Kreme [Image of the Painting]. 2011. Available online: http://isabelforbes.com/artwork/hub-city/ (accessed on 7 September 2019).

8. Hull, L. What Is Environmental Art? 2003. Available online: https://www.landviews.org/la2003/encounters-rjv.html (accessed on 7 September 2019).

9. Wallen, R. Ecological Art: A call for visionary intervention in a time of crisis. Leonardo 2014, 45, 234-242. [CrossRef]

10. Song, Y. Art in nature and schools: Nils-Udo. J. Aesthetic Educ. 2010, 44, 96-108. [CrossRef]

11. Tatarchuk, S.; Eick, C. Outdoor integration. Sci. Child. 2011, 48, 35-39.

12. Bokhoree, C.; Artee, J.; Ravhee, B. Environmental Clubs as Vehicles for Promoting Education for Environmental Sustainability in Mauritian Secondary Schools. Int. J. Environ. Cult. Econ. Soc. Sustain. Annu. Rev. 2012, 7, 177-190. [CrossRef]

13. Bokhoree, C.; Baldeo, R.; Desvaux-Thomas, D.; Ramprosand, S. The Role of Education in Understanding Climate Change's Impacts on Water Resources. Int. J. Clim. Chang. 2012, 3, 149-165. [CrossRef]

14. Boyes, E.; Stanisstreet, M. High school students' perceptions of how major global environmental issues might cause skin cancer. J. Environ. Educ. 1998, 29, 31-36. [CrossRef]

15. Stake, R.E. Art of Case Study Research; Sage: Thousand Oaks, CA, USA, 1995.

16. Graham, M.A. Art, ecology and art education: Locating art education in a critical place-based pedagogy. Stud. Art Educ. 2007, 48, 375-391. [CrossRef]

17. Wolcott, H.W. Ethnography: A Way of Seeing, 2nd ed.; Altamira Press: New York, NY, USA, 2008.

18. Freeman, M.; Mathison, S. Researching Children's Experiences; Guilford Press: New York, NY, USA, 2009.

19. Danielraja, R. A study of environmental awareness of students at higher secondary level. Shanlax Int. J. Educ. 2019, 7, 6-10. [CrossRef]

20. Rogayan, D.; Nebrida, E. Environmental awareness and practices of science students: Input for ecological management plan. Int. Electron. J. Environ. Educ. 2019, 9, 106-119.

21. Rodenburg, J. Pathway to stewardship: A framework for children and youth. In EarthEd: Rethinking Education on a Changing Planet; Assadourian, E., Mastney, L., Eds.; Worldwatch Institute: Washington, DC, USA, 2017; pp. 61-71.

22. Gude, O. New School Art Styles by Gude. Art Education, the Journal of the National Education Association. Available online: https:/ / naea.digication.com/omg/New_School_Art_Styles_the_Project_of_Art_Education (accessed on 6 May 2021).

23. Yeşilyurt, M.; Özdemir Balakoğlu, M.; Erol, M. The Impact of Environmental Education Activities on Primary School Students' Environmental Awareness and Visual Expressions. Qual. Res. Educ. 2020, 9, 188-216. [CrossRef]

24. Kipling, imperialism, and nature. In The Glyptodon: Stories of Natural History. 2011. Available online: http:/ theglyptodon. wordpress.com/2011/09/17/kipling-imperialism-and-nature/ (accessed on 4 May 2021).

25. Barrable, A.; Arvanitis, A. Flourishing in the forest: Looking at Forest School through a self-determination theory lens. J. Outdoor Environ. Educ. 2019, 22, 39-55. [CrossRef]

26. Özdemir-Balakoğlu, M. Emotional Perception and Aesthetic in Art Education; Aralık Kitap: Istanbul, Turkey, 2019.

27. Barrable, A. The Case for Nature Connectedness as a Distinct Goal of Early Childhood Education. Int. J. Early Child. 2019, 6, 59-70.

28. Fragkoulis, I.; Koutsoukos, M. Environmental Education through Art: A Creative Teaching Approach. Educ. Q. Rev. 2018, 1, 83-88. [CrossRef]

29. Sunassee, A.; Bokhoree, C.; Patrizio, A. Students' Empathy for the Environment through Eco-Art Place-Based Education: A Review. Ecologies 2021, 2, 13. [CrossRef]

30. Flour, P.O.S.; Makoondlall-Chadee, T.; Bokhoree, C.; Mohee, R. Structured Fuzzy Based Methodological Approach towards Sustainability Performance Assessment. Int. J. Environ. Sci. Dev. 2014, 223-227. [CrossRef] 